\title{
Melanin-based coloration covaries with ovary size in an age-specific manner in the barn owl
}

\author{
Alexandre Roulin \\ Received: 11 March 2009 /Revised: 18 May 2009 /Accepted: 20 May 2009 /Published online: 3 July 2009 \\ (C) Springer-Verlag 2009
}

\begin{abstract}
While the adaptive function of black eumelaninbased coloration is relatively well known, the function of reddish-brown pheomelanin-based coloration is still unclear. Only a few studies have shown or suggested that the degree of reddish-brownness is associated with predatorprey relationships, reproductive parameters, growth rate and immunity. To gain insight into the physiological correlates of melanin-based coloration, I collected barn owl (Tyto alba) cadavers and examined the covariation between this colour trait and ovary size, an organ that increases in size before reproduction. A relationship is expected because melanin-based coloration often covaries with sexual activity. The results showed that reddish-brown juveniles had larger ovaries than whiter juveniles particularly in individuals in poor condition and outside the breeding season, while in birds older than 2 years lightly coloured females had larger ovaries than reddish-brown conspecifics. As barn owls become less reddish-brown between the first and second year of age, the present study suggests that reddish-brown pheomelanic and whitish colorations are associated with juvenile- and adult-specific adaptations, respectively.
\end{abstract}

Keywords Barn owl - Covariation · Eumelanin · Pheomelanin · Ovary

\section{Introduction}

In both vertebrates and invertebrates, the deposition of melanin pigments is responsible for many colourful traits.

A. Roulin $(\bowtie)$

Department of Ecology and Evolution, Biophore,

University of Lausanne,

1015 Lausanne, Switzerland

e-mail: Alexandre.Roulin@unil.ch
While melanin-based coloration plays an important role in camouflage in many organisms (Majerus 1998; Nachman et al. 2003; Roulin and Wink 2004; Caro 2005), the importance of this type of coloration in social interactions remains elusive. To gain insight into the potential adaptive function of melanin-based coloration, and particularly to identify the potential benefits an individual may derive by mating with a darkly or lightly coloured partner, an approach is to determine whether coloration is associated with physiological and behavioural traits. Dark colorations are due to the deposition of either pheomelanin pigments responsible for reddish-brown coloration or eumelanin pigments that give black and grey colorations. A recent review of the empirical literature has shown that in vertebrates the degree of blackness is frequently associated with sexual behaviour, aggressiveness, resistance to stressors and body mass (Ducrest et al. 2008). This indicates that eumelanin-based coloration can signal aspects of individual quality (McGraw 2008) and thereby be involved in mate choice as shown in a number of species (e.g. Burley 1977; Dunn et al. 2008; Fox et al. 2002; Houtman and Falls 1994).

Much less is known about whether pheomelanin-based traits covary with similar phenotypic traits, as few studies have been carried on this aspect. In adult European rollers (Coracias garrulous) and western bluebirds (Sialia mexicana), redder males were heavier (Silva et al. 2008; Budden and Dickinson 2009); in eastern bluebirds (Sialia sialis), redder males started reproductive activities earlier and produced more offspring (Siefferman and Hill 2003); while in the yellow warbler (Dendroica petechia), browner males fed their brood at a lower rate during incubation and chick rearing (Studd and Robertson 1985). In crossfostering experiments, redder tawny owl (Strix aluco) mothers produced heavier foster offspring (Roulin et al. 
2004a); body mass of nestlings raised by foster parents was positively correlated with reddish-brown coloration of their biological mother both in the tawny owl and the barn owl (Tyto alba) (Roulin et al. 2004a, 2008; Piault et al. 2009). Another experiment in the tawny owl showed that dark reddish-brown females maintained a stronger level of antibody specifically directed against a vaccine for a longer period of time compared to pale reddish-brown females, but at a cost in terms of greater loss of body mass (Gasparini et al. 2009; see also Galeotti and Sacchi 2003). Finally, in the barn owl, dark reddish-brown males fed their brood at a higher rate than paler conspecifics and therefore they produced more fledglings (Roulin et al. 2001a). As we can see from this review, there is yet no data on a potential link between pheomelanin-based coloration and physiological parameters associated with reproductive activities. This contrasts with the situation prevailing for eumelanin-based coloration showing that in vertebrates darker eumelanic individuals are sexually more active and have higher amount of plasma circulating testosterone levels (Ducrest et al. 2008).

As variation in reproductive success is usually higher in males than in females, most researchers interested in sexual selection theory have searched for covariation between gonad size, sex steroids and eumelanin-based coloration in males (Bubenik and Bubenik 1985; Møller and Erritzøe 1988; Hill 1994; West and Packer 2002; Roulin et al. 2004b; Bókony et al. 2008). Much less interest has been devoted to female-specific sexual functions even though females often vary in conspicuous traits such as coloration. Searching for covariation between female coloration and other phenotypic attributes is interesting for two reasons. First, significant covariation may indicate that females signal their quality to males who compete to secure the best partners (Owens and Thompson 1994; Johnstone et al. 1996; Kokko and Johnstone 2002; Amundsen and Pärn 2006; Kraaijeveld et al. 2007). Second, even if variation in female coloration plays no role in male mate choice, a significant covariation may indicate that the production of pheomelanin-based coloration is associated with physiological parameters either because colour production is condition dependent or because genes involved in pheomelanogenesis have pleiotropic effects. The 'pleiotropy hypothesis' implies that some of the variation in plumage coloration is selectively neutral or even maladaptive because the evolution of coloration is genetically constrained by genetically correlated traits (e.g. Kraaijeveld and Reumer 2008). Selection on correlated traits could produce non-adaptive plumage colour until counterselection reduces the genetic linkage (e.g. Lande 1987).

In the barn owl, individuals vary continuously from dark reddish-brown to white (a pheomelanin-based trait) and from lightly to heavily marked with black spots of varying size (eumelanin-based traits), two heritable traits that are not or weakly condition dependent in their expression (Roulin et al. 1998, 2008; Roulin and Dijkstra 2003; Roulin 2004). Members of the two sexes can display any phenotype but females are on average darker pheomelanic and display more and larger black spots than males; the two colour traits are genetically correlated between the sexes, dark parents producing darkly coloured daughters and sons (Roulin et al. 2001a). The size of black spots is positively associated with calcium physiology, gland size, feather quality, the ability to resist stressful environments and parasites, age at first reproduction and survival (Table 1), while lightly pheomelanic females initiate reproductive activities earlier in the season than dark reddish-brown females and they produce offspring that are better able to grow rapidly in high quality environments (Table 1). Males appear to select their partner and to adjust reproductive investment based on the degree of female eumelanic coloration (Roulin 1999; Roulin and Altwegg 2007), while the exact role played by pheomelanin-based coloration in mate choice is still unclear. In the present paper, my intention is to investigate whether pheomelanin-based or eumelanin-based coloration is associated with ovary size measured in dead individuals. This species is particularly suited for such a study because the reproductive season is very long (February to November), and thus individuals found dead during the whole year can be used in an analysis. In animals, ovary size is positively associated with photoperiod (Horseman et al. 1978; Velarde et al. 2002), the onset of reproductive activities and food supply (Henderson et al. 2000; Stelzer 2001; Bagg et al. 2004) and with clutch size (Trouvé et al. 1999; Henderson et al. 2000) but not with egg size (Trouvé et al. 1999; Stelzer 2001).

\section{Materials and methods}

From 1996 to 2008, I measured the size of ovaries in 242 cadavers collected dead along French highways in the Champagne and Lorraine regions (ten individuals in 1996, 49 in 1997, 26 in 1998, 29 in 1999, 32 in 2000, nine in 2001, 17 in 2003, ten in 2004, 12 in 2005, 13 in 2006, 28 in 2007 and seven in 2008). The 'Société des Autoroutes Paris-Rhin-Rhône APRR' collected bodies daily, and thus dead animals stayed less than a day on the roadside before being frozen at $-20^{\circ} \mathrm{C}$. I identified sex after gonad inspection. Two hundred and four individuals with a bursa of Fabricius were denoted 'juveniles' and 38 individuals without any bursa of Fabricius and that already moulted one or several primary or secondary wing feathers were classed as 'adults' (i.e. $\geq 2$-year-old; Taylor 1993; personal observation). (I did not consider 27 individuals without any bursa of Fabricius and for which all wing feathers were 
Table 1 Summary of published studies carried out on the covariation between melanin-based plumage traits and other phenotypic traits in the barn owl

\begin{tabular}{|c|c|c|c|}
\hline Female & & Male & \\
\hline Eumelanism & Pheomelanism & Eumelanism & Pheomelanism \\
\hline
\end{tabular}

\begin{tabular}{|c|c|c|c|c|c|c|c|c|c|c|}
\hline \multicolumn{11}{|l|}{ Skeleton } \\
\hline Bill length & 0 & 0 & & & 0 & 0 & 0 & & 0 & Roulin 1999, 2006 \\
\hline Tarsus length & 0 & 0 & & & 0 & 0 & 0 & & 0 & Roulin 1999, 2006 \\
\hline Bone calcium concentration & + & & & 0 & & + & & 0 & & Roulin et al. 2006 \\
\hline \multicolumn{11}{|l|}{ Organ size } \\
\hline Size of bursa of Fabricius & - & & & & & 0 & & & & Roulin et al. 2001b \\
\hline Uropygial gland mass & - & & & 0 & & - & & 0 & & Roulin 2007 \\
\hline Heart mass & & & & + & & & & + & & Roulin et al. 2001a \\
\hline Testes size & & & & & & & & 0 & & Roulin et al. $2004 \mathrm{~b}$ \\
\hline Ovary size & 0 & & & $+;-$ & & & & & & Present study \\
\hline \multicolumn{11}{|l|}{ Feather quality } \\
\hline Wing length & 0 & 0 & & & + & 0 & 0 & & 0 & Roulin 1999, 2006 \\
\hline Tail length & + & 0 & & & 0 & 0 & 0 & & + & Roulin 1999, 2006 \\
\hline Wing and tail feather mass & + & & & 0 & & + & & 0 & & Roulin 2007 \\
\hline $\begin{array}{l}\text { Ability to produce a symmetric } \\
\text { phenotype }\end{array}$ & 0 & + & & & 0 & + & 0 & & & Roulin et al. 2003; Roulin 2004 \\
\hline Preening behaviour & - & & & 0 & & - & & 0 & & Roulin 2007 \\
\hline \multicolumn{11}{|l|}{ Immune parameters } \\
\hline Antibody production & 0 & + & & & 0 & 0 & 0 & & & Roulin et al. 2000; Roulin 2004 \\
\hline $\begin{array}{l}\text { Resistance to ectoparasites } \\
\text { (parasite load) }\end{array}$ & 0 & & + & & & & & 0 & & Roulin et al. $2001 \mathrm{~b}$ \\
\hline $\begin{array}{l}\text { Resistance to ectoparasites } \\
\text { (parasite fecundity) }\end{array}$ & 0 & + & + & & 0 & & 0 & 0 & & Roulin et al. 2001b; Roulin 2004 \\
\hline \multicolumn{11}{|l|}{ Hormone levels } \\
\hline Testosterone level & & & & 0 & & & & 0 & & Roulin et al. $2004 b$ \\
\hline Baseline corticosterone level & & & & & & 0 & & 0 & & Almasi et al. 2008 \\
\hline \multicolumn{11}{|l|}{$\begin{array}{l}\text { Resistance to elevated } \\
\text { corticosterone level }\end{array}$} \\
\hline $\begin{array}{l}\text { Body mass growth in stressful } \\
\text { environments }\end{array}$ & + & & + & & 0 & & & & $0-$ & $\begin{array}{l}\text { Roulin et al. 2003; Roulin 2009; Almasi et } \\
\text { al. } 2008\end{array}$ \\
\hline $\begin{array}{l}\text { Body mass growth in relaxed } \\
\text { environments }\end{array}$ & & & - & & + & & & & + & Roulin et al. 2003, 2008 \\
\hline $\begin{array}{l}\text { Resistance to injection } \\
\text { of corticosterone }\end{array}$ & & & & & & + & & & & Almasi et al. 2008 \\
\hline \multicolumn{11}{|l|}{ Fitness components } \\
\hline Age at first reproduction & + & & & 0 & & 0 & & 0 & & Roulin and Altwegg 2007 \\
\hline Hatching date & & & & + & & & & 0 & & Roulin et al. 2001a \\
\hline Clutch size & & & & 0 & & & & 0 & & Roulin et al. 2001a \\
\hline Brood size at hatching & & & & 0 & & & & 0 & & Roulin et al. 2001a \\
\hline Brood size at fledging & & & & 0 & & & & + & & Roulin et al. 2001a \\
\hline Feeding rate & & & & 0 & & $-; 0$ & & $+; 0$ & & Roulin et al. 2001a; Almasi et al. 2008 \\
\hline Survival & + & & & 0 & & 0 & & 0 & & Roulin and Altwegg 2007 \\
\hline
\end{tabular}

Black eumelanic (i.e. diameter of spots located on the tip of feathers) and reddish-brown pheomelanic colorations are distinguished. Columns A indicate the sign of covariation between melanin-based coloration and other phenotypic traits measured within individuals (e.g. darker eumelanic females have a longer tail); columns B indicate the sign of covariation between colour traits measured in biological parents and other phenotypic traits measured in their offspring raised in a foster nest (e.g. darker pheomelanic fathers produce longer-tailed offspring that were raised by foster parents); columns $\mathrm{C}$ report the sign of covariation between colour traits measured in parents and phenotypic traits measured in their non-crossfostered offspring 
seemingly of the same generation because there was some doubt about their age.) Juveniles were collected between 5 August and 12 April (mean $\pm \mathrm{SD}=5$ December \pm 42 days) and adults between 13 August and 18 June (17 January \pm 75 days). Body mass ( $298 \pm 25 \mathrm{~g})$ was given by the difference between the mass measured on the day of collection minus the mass of the stomach contents $(11.9 \pm$ $12.0 \mathrm{~g}$ ); I removed stomach contents to minimise variation in body mass due to recent meals. I measured the length $(13.2 \pm 2.7 \mathrm{~mm})$ and width $(4.6 \pm 1.5 \mathrm{~mm})$ of ovaries to the nearest $0.1 \mathrm{~mm}$; mass of ovaries was not recorded because of the difficulty of extracting them. In eight adults and 62 juveniles, I measured the diameter of the largest follicle to the nearest $0.1 \mathrm{~mm}(1.4 \pm 0.6 \mathrm{~mm})$ to investigate whether this measure is correlated with ovary size, and thus with the degree of ovary maturation and in turn reproductive activities (e.g. Wikelski et al. 2000).

On the breast of each individual, I scored pheomelaninbased coloration by comparison with eight colour chips ranging from I for reddish-brown to VIII for white. Then, I placed a $60 \times 40 \mathrm{~mm}$ frame within which I counted black spots located at the tip of feathers and measured their diameter to the nearest $0.1 \mathrm{~mm}$. Methods of assessing plumage traits are reliable (Roulin 1999, 2004). Because some individuals were damaged, I could not measure all plumage traits in all individuals, explaining discrepancies in sample sizes between analyses. Juveniles were darker pheomelanic than adults (juveniles - 3.49 \pm 1.03 ; adults$4.37 \pm 1.55$; Student's $t$ test $\left.-t_{240}=4.43, P<0.0001\right)$ and displayed smaller $\left(1.22 \pm 0.36 \mathrm{~mm}\right.$ vs. $1.38 \pm 0.48 \mathrm{~mm} ; t_{236}=$ 2.42, $P=0.016)$ but more black spots $(52.5 \pm 23.4$ vs. $44.6 \pm$ $\left.22.1 ; t_{236}=-1.89, P=0.059\right)$. These age-specific patterns are due to the fact that between the first and second year of age females become less pheomelanic and lose spots that also become larger (unpublished data). Nevertheless, an individual that is darker and more spotted than another individual at the juvenile stage is still darker and more spotted at adulthood (Roulin and Dijkstra 2003). Barn owls can start to reproduce at the first year of age and the first moult of body feathers takes place not before the second year. As already shown in a Swiss population (Roulin 2004), darker pheomelanic owls displayed more (Pearson correlation, $r=-0.29, n=233, P<0.0001)$ and larger black spots $(r=-0.28, n=238, P<0.0001)$, and number and size of black spots were positively correlated $(r=0.43, n=233$, $P<0.0001)$. Since ovaries are larger during the reproductive period (Horseman et al. 1978; Henderson et al. 2000; Stelzer 2001; Velarde et al. 2002; Baag et al. 2004), I statistically controlled for the number of days separating date of cadaver collection and the 1st of August, an arbitrary date for the end of the mating season for adults (in our population, egg laying dates span from 25 February to 30 July) and for the time of independence for juveniles.
For instance, number of days between the 13th of March vs. 2nd of September and the 1st of August is 224 and 32, respectively. In both juveniles and adults, plumage traits were neither correlated with date of cadaver collection nor with body mass (Pearson correlations, $P$ values $>0.24$ ).

All statistical analyses were performed with the package JMP IN 5.1 (SAS Institute Inc., Cary, NC, USA), are twotailed and $P$ values smaller than 0.05 considered significant. Means are quoted \pm SD.

\section{Results}

Follicle size was positively associated with ovary width (ANCOVA with follicle size as dependent variable, $F_{1,63}=$ $29.86, P<0.0001)$ but not with ovary length $\left(F_{1,63}=2.60\right.$, $P=0.11)$ after controlling for date $\left(F_{1,63}=3.25, P=0.07\right.$; follicles tended to increase from the 1st of August onwards) and age $\left(F_{1,63}=7.43, P=0.008\right.$; follicles were smaller in juveniles than in adults). Ovary width is thus an appropriate proxy of developmental stage of follicles, and for this reason I consider only this measure in subsequent analyses.

In an ANCOVA with ovary width as dependent variable and age (juvenile vs. adult; $F_{1,225}=19.57, P<0.0001$ ), pheomelanin-based coloration $\left(F_{1,225}=2.07, P=0.15\right)$, number of spots $\left(F_{1,225}=0.04, P=0.85\right)$ and spot diameter $\left(F_{1,225}=0.004, P=0.95\right)$ as four independent variables, only the interaction between age and pheomelanin-based coloration was significant $\left(F_{1,225}=15.41, P=0.0001\right)$ but not the interactions between age and number of spots $\left(F_{1,225}=1.55\right.$, $P=0.21)$ and between age and spot diameter $\left(F_{1,225}=1.78\right.$, $P=0.18$ ). In juveniles, darker reddish-brown females had wider ovaries mainly when individuals had a low body mass (significant interaction between pheomelanin-based coloration and body mass in Table 2; Fig. 1). Furthermore, the negative relationship between pheomelanin-based coloration and ovary size was detected only outside the breeding season (significant interaction between pheomelanin-based coloration and date in Table 2). In contrast to juveniles, ovaries were bigger in whitish than reddish-brown adults (Fig. 2; Table 2); interactions between coloration, body mass and date were not significant (Table 2). In these models, I did not control for the variable 'year' because it did not explain any significant part of the variation in ovary width $(P$ values $>0.12$ ). In juveniles and adults, ovary size increased with body size and from the 1st of August onwards (Table 2).

\section{Discussion}

In French barn owls, ovary size was associated with the degree of pheomelanin-based coloration in interaction with age. In juveniles, ovaries were wider in dark than lighter 
Table 2 Stepwise multiple regression on $\log _{10}$-transformed ovary width with breast pheomelanin-based coloration, date (i.e. number of days separating date of cadaver collection and the first of August, an arbitrary date for the end of the mating season in adults and for the time of independence in juveniles) and body mass as three independent variables

\begin{tabular}{lrcc}
\hline & \multicolumn{1}{l}{$F$} & $d f$ & \\
\hline Juvenile & & & \\
Pheomelanism (P) & 0.05 & 1,264 & 0.83 \\
Body mass (B) & 30.61 & 1,264 & $<0.0001$ \\
Date (D) & 66.09 & 1,264 & $<0.0001$ \\
$\mathrm{P} \times \mathrm{D}$ & 7.00 & 1,264 & 0.009 \\
$\mathrm{P} \times \mathrm{B}$ & 9.64 & 1,264 & 0.0021 \\
$\mathrm{~B} \times \mathrm{D}$ & 1.79 & 1,263 & 0.18 \\
$\mathrm{P} \times \mathrm{D} \times \mathrm{B}$ & 0.06 & 1,262 & 0.81 \\
Adult & & & \\
$\mathrm{Pheomelanism} \mathrm{(P)}$ & 9.74 & 1,34 & 0.004 \\
Body mass (B) & 12.78 & 1,34 & 0.001 \\
Date $(\mathrm{D})$ & 5.56 & 1,34 & 0.024 \\
$\mathrm{P} \times \mathrm{D}$ & 3.77 & 1,33 & 0.06 \\
$\mathrm{P} \times \mathrm{B}$ & 0.76 & 1,31 & 0.39 \\
$\mathrm{~B} \times \mathrm{D}$ & 1.00 & 1,32 & 0.32 \\
$\mathrm{P} \times \mathrm{D} \times \mathrm{B}$ & 1.11 & 1,30 & 0.30 \\
\hline
\end{tabular}

I removed non-significant interactions starting with the least significant ones, explaining why degrees of freedoms vary between factors. Separate tests were carried out for juveniles and adults

pheomelanic females particularly in individual in poor condition (Fig. 1) and outside the breeding season, while in adults the opposite relationship was found with ovaries being wider in light than darker pheomelanic females (Fig. 2) independently of date and body mass.

In female birds, variation in plumage traits is often associated with laying date, clutch size and egg size (Kraaijeveld et al. 2007). In a previous study in the barn owl, we showed that lightly reddish-brown individuals lay their clutch earlier in the season than dark reddish-brown conspecifics (Roulin et al. 2001a), a relationship detected in adults but not in yearlings (Dreiss and Roulin, unpublished data). These unpublished results are consistent with the present study as ovaries were bigger in less pigmented pheomelanic adult females. Development of ovaries relies in part on luteinising hormone (LH), follicle-stimulating hormone (FSH) and sex steroids (Wingfield and Farner 1993) for which the level is partly under the control of melanocortins and agouti-signalling protein. The latter two hormones are involved in melanogenesis providing a potential proximate link between ovary size and melaninbased coloration (Ducrest et al. 2008).

Has the covariation between laying date, ovary size and pheomelanin-based coloration a genetic basis or is it environmentally induced? Evidence for a relationship
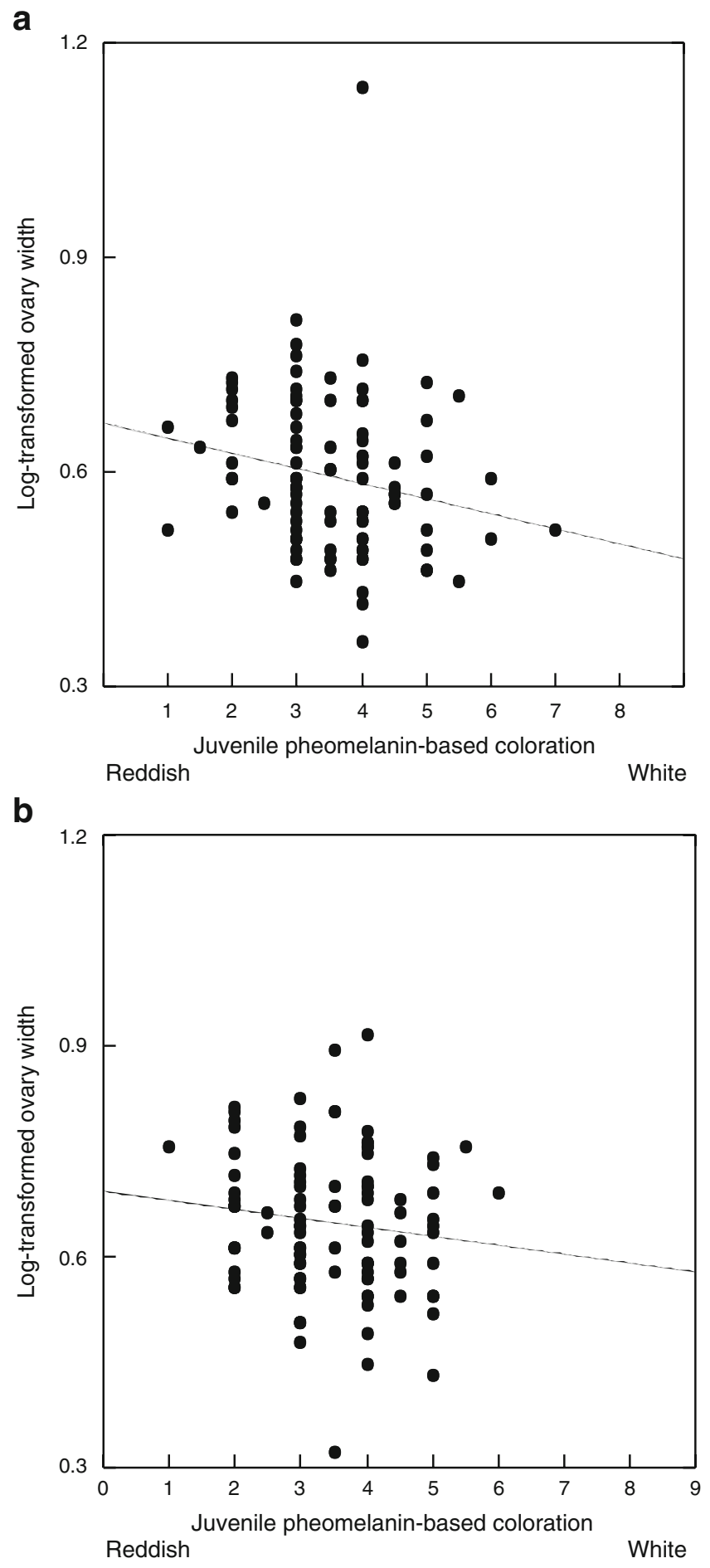

Fig. 1 Relationship between $\log _{10}$-transformed ovary width and pheomelanin-based coloration in juvenile barn owls for which body mass is a below or $\mathbf{b}$ above the median (298 g). Regression lines are drawn for illustrative purpose

between coloration and laying date comes from a study performed in Switzerland, while the covariation with ovary size has been detected in France, the two populations being distant of $260 \mathrm{~km}$. Sign of covariation 


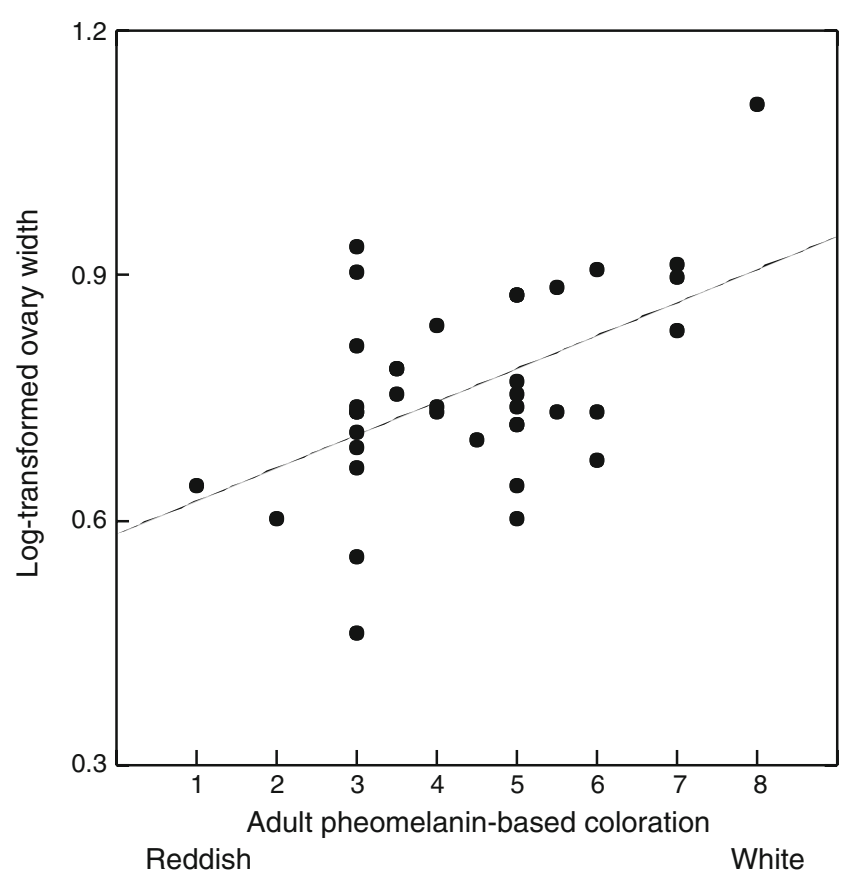

Fig. 2 Relationship between $\log _{10}$-transformed ovary width and pheomelanin-based coloration in adult barn owls. Regression line is drawn for illustrative purpose

between pheomelanin-based coloration and ovary size changes with age, an observation which is not consistent with the hypothesis of environmentally induced effects. This hypothesis would indeed imply that environmental conditions prevailing in France are favourable for dark owls in the first year of life but disadvantageous at adulthood. For this reason, I privilege the hypothesis that genes creating variation in the degree of pheomelaninbased coloration pleiotropically regulate sexual activities including ovary development. As recently suggested for vertebrates, the melanocortin system may provide a link between melanin-based coloration and other phenotypic traits including those associated with sexual activities and production of $\mathrm{LH}, \mathrm{FSH}$, testosterone and progesterone (Ducrest et al. 2008). Because birds become lighter coloured between the first and second year of age, the expression of genes involved in the melanocortin system may change between these two age classes potentially explaining why sign of the covariation between coloration and ovary size is different in juveniles and adults. Furthermore, gene expression might be sensitive to environmental factors as I found that the relationship between ovary size and pheomelanin-based coloration is stronger when juveniles are in poor condition and outside the breeding season. Context-dependent covariation between the degree of pheomelanin-based coloration and other phenotypic traits such as body condition has already been found in both the barn owl and tawny owl (Roulin et al. 2008; Piault et al. 2009). These studies showed that, when food is available in large quantities, dark pheomelanic nestlings grow better than lighter pheomelanic conspecifics. The present study shows that poor condition, as measured by body mass, negatively affects ovary size, an effect that is less pronounced in darker reddish-brown juvenile females.

The finding that the sign of covariation between pheomelanin-based coloration and ovary width is negative in juveniles and positive in adults has important implications to understand the potential adaptive value of colour change with age. In many organisms, individuals change in coloration with age between the first and second year of life (e.g. Beauchamp 2003), a frequent pattern in species displaying melanin-based coloration (e.g. Ferguson-Lees and Christie 2001). Although we can suspect that juvenileand adult-specific colorations are associated with agedependent adaptations (e.g. Vergara and Fargallo 2007), no clear advantage of being darkly pheomelanic at the juvenile stage and whitish at adulthood has yet been found. In many birds, individuals become more brightly coloured between the first and second year of age (e.g. Rohwer et al. 1980) probably due to physiological changes that might also trigger the age-dependent increase in reproductive success (Sæther 1990). For example, in black-headed grosbeaks Pheucticus melanocephalus, testis mass is positively associated with plumage brightness in yearlings but not in adults (Hill 1994). The present study in the barn owl suggests that the change from dark reddish-brown to a lighter coloration between the first and second year of age is associated with an improvement in fitness-related traits. Data in other animal species are required to examine whether results found in the barn owl are applicable to other species in which individuals vary in the degree of melanin-based coloration.

Assuming that in the barn owl the covariation between ovary size and pheomelanin-based coloration is partly under genetic control, selection on ovary size may constrain the evolution of plumage colour (e.g. Kraaijeveld and Reumer 2008). This non-adaptive genetic linkage may persist because selection needs to be strong and exerted during long periods of time to break down a genetic correlation (Lande 1987). Thus, it remains to tackle whether covariation between coloration and ovary size is adaptive or not both at the juvenile and adult stages, and whether males assess female pheomelanin-based coloration to select a partner. This proposition is interesting because it would imply that mate choice decisions are age dependent. However, I can still not exclude the possibility that covariation between ovary size and coloration is the result of selection being exerted in males rather in females. Hormones generating such a covariation may indeed have a more important function in males. For example, we found 
that in some years darker reddish-brown males invest more in feeding their progeny (Roulin et al. 2001a), a trait that might be regulated by sex steroids that could also affect female parental and sexual activities.

Signalling function of pheomelanin-based

and eumelanin-based coloration in the barn owl

Several papers have reported covariations between coloration and other phenotypic traits in the barn owl. The finding that covariations are sex specific and pigment specific led to the proposition that eumelanin-based and pheomelanin-based colorations play an important function in females and males, respectively (Roulin et al. 2001b; Roulin and Altwegg 2007). Furthermore, several observations and experiments showed that eumelanic and pheomelanic individuals are best adapted to poor and rich environments, respectively (Roulin et al. 2008). Table 1 shows that the degree of eumelanin-based coloration is positively associated with calcium physiology, gland size, feather quality, the ability to resist stressful environments and parasites, age at first reproduction and survival. Interestingly, the degree of pheomelanin-based coloration is associated with other phenotypic traits including heart mass, ovary size, wing and tail length, reproductive parameters, feeding rate, as well as the ability to grow rapidly in high quality environments. Even if in the barn owl eumelanin-based coloration is believed to be a female ornament and pheomelanin-based coloration a male ornament (Roulin 1999; Roulin and Altwegg 2007), the two colour traits were found to covary with other phenotypic traits in the two sexes probably because the genetic correlation between the sexes is strong (Roulin et al. 2001a).

Melanic colorations are correlated with many phenotypic traits (Table 1; see also Jawor and Breitwisch 2003; Ducrest et al. 2008) and for this reason it might be difficult to draw an exhaustive list without understanding the underlying proximate mechanisms. Thus, our current research goal is to identify the genes involved in melanogenesis that pleiotropically regulate other phenotypic traits as explained in Ducrest et al. (2008). Melanogenesis is a process that is well conserved in vertebrates implying that knowledge accumulated in model organisms such as mice can be used to derive predictions regarding which gene might generate covariations between melanin-based coloration and other phenotypic traits. Preliminary results are promising in showing that, as expected from Ducrest et al. (2008), the proopiomelanocortin gene is polymorphic and associated with the degree of melanic pigmentation in the barn owl. Investigating proximate genetic mechanisms will provide useful insights into the exact adaptive function of melaninbased traits in both females and males. This is also necessary to determine why some phenotypic traits are associated only with pheomelanin-based coloration as found for ovary size in the present study, only with eumelanin-based coloration or with both colour traits. This is particularly important because in some cases the two categories of melanin-based colour traits provide redundant information on specific phenotypic attributes such as resistance to oxidative stress (unpublished data) or information on different traits. As can be seen, the study of the adaptive function of melanin-based coloration is complex probably because genes involved in melanogenesis pleiotropically regulate many other phenotypic traits.

Acknowledgements I thank Hughes Baudvin for having organised the collection of dead barn owls along French highways by the SAPRR (Société des Autoroutes Paris-Rhin-Rhône) and the Swiss National Science Foundation (grant PPOOA-102913) for financial support. Ken Kraaijeveld and an anonymous referee kindly provided useful comments to improve the manuscript.

\section{References}

Almasi B, Roulin A, Jenni-Eiermann S, Jenni L (2008) Parental investment and its sensitivity to corticosterone is linked to melanin-based coloration in barn owls. Horm Behav 54:217-223

Amundsen T, Pärn H (2006) Female coloration: review of functional and nonfunctional hypotheses. In: Hill GE, McGraw KJ (eds) Bird coloration, function and evolution. Harvard University Press, Cambridge, pp 280-345

Baag MA, Vassena R, Papasso-Brambilla E, Grupen CG, Armstrong DT, Gandolfi F (2004) Changes in ovarian, follicular, and oocyte morphology immediately after the onset of puberty are not accompanied by an increase in oocyte developmental competence in the pig. Theriogenol 62:1003-1011

Beauchamp G (2003) Delayed maturation in birds in relation to social foraging and breeding competition. Evol Ecol Res 5:589-596

Bókony V, Garamszegi LZ, Hirschenhauser K, Liker A (2008) Testosterone and melanin-based black plumage coloration: a comparative study. Behav Ecol Sociobiol 62:1229-1238

Bubenik GA, Bubenik AB (1985) Seasonal variations in hair pigmentation of white-tailed deer and their relationship to sexual activity and plasma testosterone. J Exp Zool 235:387-395

Budden AE, Dickinson JL (2009) Signals of quality and age: the information content of multiple plumage ornaments in male western bluebirds Sialia mexicana. J Avian Biol 40:18-27

Burley N (1977) Parental investment, mate choice, and mate quality. Proc Natl Acad Sci U S A 74:3476-3479

Caro T (2005) The adaptive significance of coloration in mammals. Bioscience 55:125-136

Ducrest A-L, Keller L, Roulin A (2008) Pleiotropy in the melanocortin system, coloration and behavioural syndromes. Trends Ecol Evol 23:502-510

Dunn PO, Whittingham LA, Freeman-Gallant CR, DeCoste J (2008) Geographic variation in the function of ornaments in the common yellowthroat Geothlypis trichas. J Avian Biol 39:66-72

Ferguson-Lees J, Christie DA (2001) Raptors of the world. Helm Identification Guides. Helm, London

Fox S, Johnson CN, Brooks R, Lewis MJ (2002) Polymorphism, mate choice and sexual selection in the Gouldian finch (Erythrura gouldiae). Aust J Zool 50:125-134

Galeotti P, Sacchi R (2003) Differential parasitaemia in the tawny owl (Strix aluco): effects of colour morphs and habitat. J Zool 261:91-99 
Gasparini J, Bize P, Piault R, Wakamatsu K, Blount JD, Ducrest A-L, Roulin A (2009) Strength and cost of an induced immune response are associated with a heritable melanin-based colour trait in female tawny owls. J Anim Ecol 78(3):608-616

Henderson BA, Trivedi T, Collins N (2000) Annual cycle of energy allocation to growth and reproduction of yellow perch. J Fish Biol 57:122-133

Hill GE (1994) Testis mass and subadult plumage in black-headed grosbeaks. Condor 96:626-630

Horseman ND, Smith CA, Culley DD (1978) Effects of age and photoperiod on ovary size and condition in bullfrogs (Rana catesbeiana Shaw) (Amphibia, Anura, Ranidae). J Herpetol 12:287-290

Houtman AM, Falls JB (1994) Negative assortative mating in the white-throated sparrow, Zonotrichia albicollis: the role of mate choice and intra-sexual competition. Anim Behav 48:377-383

Jawor JM, Breitwisch R (2003) Melanin ornaments, honesty, and sexual selection. Auk 120:249-265

Johnstone RA, Reynolds JD, Deutsch JC (1996) Mutual mate choice and sex differences in choosiness. Evolution 50:1382-1391

Kokko H, Johnstone RA (2002) Why is mutual mate choice not the norm? Operational sex ratios, sex roles and the evolution of sexually dimorphic and monomorphic signalling. Phil Trans R Soc Lond B 357:319-330

Kraaijeveld K, Reumer BM (2008) Constraints and the evolution of mutual ornamentation. In: Weber EA, Krause LH (eds) Animal behaviour, new research. Nova, New York

Kraaijeveld K, Kraaijeveld FJL, Komdeur J (2007) The evolution of mutual ornamentation. Anim Behav 74:657-677

Lande R (1987) Genetic correlations between the sexes in the evolution of sexual dimorphism and mating preferences. In: Bradbury JW, Andersson MB (eds) Sexual selection: testing the alternatives. Wiley, London, pp 83-94

Majerus MEN (1998) Melanism, evolution in action. Oxford University Press, Oxford

McGraw KJ (2008) An update on the honesty of melanin-based color signals in birds. Pigment Cell Melanoma Res 21:133-138

Møller AP, Erritzøe J (1988) Badge, body and testes sizes in house sparrow Passer domesticus. Ornis Scand 19:72-73

Nachman MW, Hoekstra HE, D'Agostino SL (2003) The genetic basis of adaptive melanism in pocket mice. Proc Natl Acad Sci U S A 100:5268-5273

Owens IPF, Thompson DBA (1994) Sex differences, sex ratios and sex roles. Proc R Soc Lond B 258:93-99

Piault R, Gasparini J, Bize P, Jenni-Eiermann S, Roulin A (2009) Pheomelanin-based coloration and the ability to cope with variation in food supply and parasitism. Am Nat (in press)

Rohwer S, Fretwell SD, Niles DM (1980) Delayed maturation in passerine plumages and the deceptive acquisition of resources. Am Nat 115:400-437

Roulin A (1999) Nonrandom pairing by male barn owls Tyto alba with respect to a female plumage trait. Behav Ecol 10:688695

Roulin A (2004) Proximate basis of the covariation between a melanin-based female ornament and offspring quality. Oecologia 140:668-675

Roulin A (2006) Linkage disequilibrium between a melanin-based colour polymorphism and tail length in the barn owl. Biol J Linn Soc $88: 475-488$

Roulin A (2007) Melanin pigmentation negatively correlates with plumage preening effort in barn owls. Funct Ecol 21:264-271

Roulin A (2009) Covariation between eumelanic pigmentation and body mass only under specific conditions. Naturwissenschaften 96:375-382
Roulin A, Altwegg R (2007) Breeding rate is associated with pheomelanism in male and with eumelanism in female barn owls. Behav Ecol 18:563-570

Roulin A, Dijkstra C (2003) Genetic and environmental components of variation in eumelanin and phaeomelanin sex-traits in the barn owl. Heredity 90:359-364

Roulin A, Wink M (2004) Predator-prey relationships and the evolution of genetic colour polymorphism. Biol J Linn Soc 81:565-578

Roulin A, Richner H, Ducrest A-L (1998) Genetic, environmental and condition-dependent effects on female and male plumage ornamentation. Evolution 52:1451-1460

Roulin A, Jungi TW, Pfister H, Dijkstra C (2000) Female barn owls (Tyto $a l b a$ ) advertise good genes. Proc R Soc Lond B 267:937-941

Roulin A, Riols C, Dijkstra C, Ducrest A-L (2001a) Female- and malespecific signals of quality in the barn owl. J Evol Biol 14:255-267

Roulin A, Riols C, Dijsktra C, Ducrest A-L (2001b) Female plumage spottiness and parasite resistance in the barn owl (Tyto alba). Behav Ecol 12:103-110

Roulin A, Ducrest A-L, Balloux F, Dijkstra C, Riols C (2003) A female melanin-ornament signals offspring fluctuating asymmetry in the barn owl. Proc R Soc Lond B 270:167-171

Roulin A, Bize P, Ravussin P-A, Broch L (2004a) Genetic and environmental effects on the covariation between colour polymorphism and a life-history trait. Evol Ecol Res 6:1253-1260

Roulin A, Müller W, Sasvári L, Dijkstra C, Ducrest A-L, Riols C, Wink M, Lubjuhn T (2004b) Extra-pair paternity, testes size and testosterone level in relation to colour polymorphism in the barn owl Tyto alba. J Avian Biol 35:492-500

Roulin A, Dauwe T, Blust R, Eens M, Beaud M (2006) A link between eumelanism and calcium physiology in the barn owl. Naturwissenschaften 93:426-430

Roulin A, Gasparini J, Bize P, Ritschard M, Richner H (2008) Melanin-based colorations signal strategies to cope with poor and rich environments. Behav Ecol Sociobiol 62:507-519

Sæther BE (1990) Age-specific variation in reproductive performance of birds. Curr Ornithol 7:251-283

Siefferman L, Hill GE (2003) Structural and melanin coloration indicate parental effort and reproductive success in male eastern bluebirds. Behav Ecol 14:855-861

Silva N, Avilés JM, Danchin E, Parejo D (2008) Informative content of multiple plumage-coloured traits in female and male European rollers. Behav Ecol Sociobiol 62:1969-1979

Stelzer C-P (2001) Resource limitation and reproductive effort in a planktonic rotifer. Ecology 82:2521-2533

Studd MV, Robertson RJ (1985) Sexual selection and variation in reproductive strategy in male yellow warblers (Dendroica petechia). Behav Ecol Sociobiol 17:101-109

Taylor IR (1993) Age and sex determination of barn owls Tyto alba alba. Ring Migr 14:94-102

Trouvé S, Jourdane J, Renaud F, Durand P, Morand S (1999) Adaptive sex allocation in a simultaneous hermaphrodite. Evolution 53:1599-1604

Velarde RAM, Wiedenmann RN, Voegtlin DJ (2002) Influence of photoperiod on the overwintering induction of Galerucella calmariensis L. BioControl 47:587-601

Vergara P, Fargallo JA (2007) Delayed plumage maturation in Eurasian kestrels: female mimicry, subordination signalling or both? Anim Behav 74:1505-1513

West PM, Packer C (2002) Sexual selection, temperature, and the lion's mane. Science 297:1339-1343

Wikelski M, Hau M, Wingfield JC (2000) Seasonality of reproduction in a neotropical rain forest bird. Ecology 81:2458-2472

Wingfield JC, Farner DS (1993) Endocrinology of reproduction in wild species. In: Farner DS, King JR, Parker KC (eds) Avian biology. Academic, London 